\title{
REVIEW
}

\section{Can sildenafil improve physical performance at altitude? Current scientific evidence}

\author{
Andrés Toro-Salinas ${ }^{a}$, Joan Ramon Torrella ${ }^{a}$, Teresa Pagès ${ }^{a}$, \\ Casimiro Javierre ${ }^{\mathrm{b}}$, Ginés Viscor ${ }^{\mathrm{a}, *}$ \\ a Departament de Fisiologia i Immunologia, Facultat de Biologia, Universitat de Barcelona, Spain \\ b Departament de Ciències Fisiològiques II, Facultat de Medicina, Universitat de Barcelona, Spain
}

Received 2 October 2015; accepted 8 November 2015

Available online 12 January 2016

\section{KEYWORDS \\ Sildenafil; \\ High altitude; \\ PDE-5 inhibitor; \\ Exercise; \\ Hypoxia; \\ Normobaric; \\ Hypobaric}

\section{PALABRAS CLAVE}

Sildenafilo;

Gran altitud;

Inhibidor de PDE-5;

Ejercicio;

Hipoxia;

Normobárico;

Hipobárico

\begin{abstract}
Sildenafil has proven to efficiently reduce the increase in pulmonary artery pressure provoked by hypoxic pulmonary vasoconstriction. However, its role as a possible factor in increasing exercise performance under hypoxic conditions remains to be demonstrated. The use of sildenafil has increased among mountaineers, not as a high altitude pulmonary edema preventive drug, but as a means that could help to improve performance. Several studies have attempted to address this issue, with conflicting results. Currently, despite the inconclusive data at simulated or real altitude, and with the clear evidence that, in normoxia, sildenafil does not improve performance, this drug is being used (and sometimes overused) by people who climb high peaks. However, such potential performance improvement would depend on the degree of hypoxemia (altitude) and the individual responsiveness to this drug. This paper reviews the current knowledge on this matter.

(c) 2015 Consell Català de l'Esport. Generalitat de Catalunya. Published by Elsevier España, S.L.U. All rights reserved.
\end{abstract}

\section{¿Afecta sidenafilo a la capacidad física en altitud? Evidencias científicas en la actualidad}

Resumen Sildenafilo ha demostrado eficacia reduciendo la hipertensión pulmonar provocada por la vasoconstricción pulmonar hipóxica. Su papel como posible factor para aumentar el rendimiento en el ejercicio en condiciones de hipoxia está por demostrar, pero el uso de sildenafilo ha aumentado entre los montañeros, no como un fármaco preventivo del edema pulmonar de gran altitud, sino en la creencia de que podría ayudar a mejorar el rendimiento físico a gran altura geográfica. Varios estudios han tratado de abordar este tema, con resultados

\footnotetext{
* Corresponding author.

E-mail address: gviscor@ub.edu (G. Viscor).
} 
contradictorios. Actualmente, a pesar de que no hay datos concluyentes, ni en altitud simulada ni real, y con la clara evidencia de que en normoxia el sildenafilo no mejora el rendimiento físico, se continúa utilizando esta sustancia (a veces en exceso) por personas que suben a altas cumbres. Tal potencial mejora de rendimiento dependería del grado de hipoxemia (altitud) y de la capacidad de respuesta individual a este medicamento. El presente artículo revisa el conocimiento actual sobre este tema.

(C) 2015 Consell Català de l'Esport. Generalitat de Catalunya. Publicado por Elsevier España, S.L.U. Todos los derechos reservados.

\section{Mechanism of sildenafil action}

Since the work of Ghofrani et al. ${ }^{1}$ about the improvement of physical capacity during exercise in hypoxia conditions due to the use of sildenafil, ${ }^{1}$ several studies have attempted to reproduce their findings. However, to date, there is still controversy over whether phosphodiesterase type 5 (PDE-5) inhibitor is a substance that can actually improve performance under hypoxic conditions. Sildenafil has been used to treat erectile dysfunction ${ }^{2}$ through inhibition of PDE5 activity which, in turn, increases the cyclic guanosine monophosphate (cGMP) local concentration, thus causing vasodilatation by inducing relaxation of arterial wall smooth muscle fibers, especially in the corpus cavernosum and lungs. ${ }^{3}$ In the lungs, its effect is focused on the treatment of pulmonary arterial hypertension $(\mathrm{PAH})^{4,5}$ caused by the general hypoxic vasoconstriction: the vasodilation response induced by sildenafil decreases pulmonary vascular resistance, thus favoring the uptake of oxygen and increasing the arterial oxygen content $\left(\mathrm{CaO}_{2}\right)$. Sildenafil has also been used in patients suffering from diseases associated with PAH such as chronic heart failure, ${ }^{6,7}$ chronic obstructive pulmonary disease or idiopathic pulmonary fibrosis. ${ }^{8-10}$ In all these cases, sildenafil was able to decrease pulmonary artery pressure (PAP) and improve the patients exercise performance.

Apart from these medical considerations, the effect of sildenafil in PAH and hypoxic pulmonary vasoconstriction (PHV) in situations of moderate or severe hypoxia in healthy people has also attracted researchers' interest. The acute exposure to normobaric or hypobaric hypoxia produces a pulmonary vasoconstriction due to the decrease in alveolar oxygen tension $\left(\mathrm{PAO}_{2}\right)$, thus causing a reduction in oxygen diffusion from alveoli to capillaries and a consequent decrease in the oxygen transport to other tissues. ${ }^{11}$ Moreover, increased pulmonary artery pressure causes overload in the right ventricle, affecting afterload and cardiac output (CO). ${ }^{12,13}$

\section{Hypoxia and exercise}

Exposure to acute hypoxia $(\mathrm{AH})$ causes the reduction of the maximum aerobic capacity, directly affecting the exercise performance. ${ }^{14-16} \mathrm{VO}_{2 \max }$ tends to diminish in direct proportion to the decrease in $\mathrm{CaO}_{2}$, which occurs as hypoxia increases. ${ }^{17,18}$ Exercise exacerbates $\mathrm{CaO}_{2}$ reduction due to the lower uptake of $\mathrm{O}_{2}$ during gas exchanging in the lungs, ${ }^{1,19}$ which may increase the risk of pulmonary edema, ${ }^{11,20}$ especially in people predisposed to suffer this complications associated to rapid ascent. ${ }^{21}$ Considering that the increase in PAP could be an important factor limiting performance during exercise in hypoxia, ${ }^{22}$ sildenafil has been proposed as a potential ergogenic aid for physical activity in hypoxic conditions due to its possible benefits for athletic performance, and has been widely used. ${ }^{23-27}$ This could be of especial interest in some countries, such as Andean or central Asia plateaus, where many professional athletes and football and other collective sport teams have to perform or play in locations higher than $2500 \mathrm{~m}$. Finally, sildenafil use has also been promoted under the name of "Vitamin V" in some Internet forums because it supposedly improves muscle hypertrophy in bodybuilders and fitness enthusiasts. ${ }^{28}$

\section{Sildenafil effects during exercise and hypoxia}

Research conducted on healthy people, combining the effects of exercise and hypoxia after sildenafil administration, has yielded contrasting results. Studies on this subject present a wide range of designs and methodologies leaving many questions still unanswered about the possible benefits of the sildenafil administration under hypoxic conditions. The following paragraphs present a review of the most relevant studies on sildenafil administration and exercise in hypoxia. All the studies had a randomized double blind, placebo controlled and crossover design, except for Olfert et al. ${ }^{15}$ which was single-blind designed and did not use placebo. Table 1 summarizes the main methodological characteristics of the included studies.

The first published study concerning the relationship between sildenafil, exercise and hypoxia was that of Ghofrani et al. ${ }^{1}$ These authors studied a group of 14 people (12 men and 2 women) who had previous experience in altitude exposure. Data from the participants were recorded at rest and during maximum incremental exercise tests $\left(W_{\text {peak }}\right)$ in two different situations: (1) at an altitude of $171 \mathrm{~m}$ breathing through a mask of a hypoxic gas mixture with $10 \%$ fraction of oxygen for $2 \mathrm{~h}$ and (2) at an altitude of $5245 \mathrm{~m}$ after 8 days of ascent until Everest base camp. Under a random-controlled environment and $2 \mathrm{~h}$ before evaluating the participants, one dose of $50 \mathrm{mg}$ of sildenafil or one dose of placebo were administered to each group. Their results showed that sildenafil reduced the PAH at 
Table 1 Summary of the main methodological aspects of studies about the effects of sildenafil in hypoxic conditions.

\begin{tabular}{|c|c|c|c|c|c|}
\hline Report & Subjects & $\begin{array}{l}\text { Hypoxia } \\
\text { exposure }\end{array}$ & $\begin{array}{l}\text { Hypoxia } \\
\text { type }\end{array}$ & $\begin{array}{l}\text { Sildenafil } \\
\text { dosage }\end{array}$ & $\begin{array}{l}\text { Exercise } \\
\text { intensity }\end{array}$ \\
\hline $\begin{array}{l}\text { Ghofrani } \\
\text { et al. (2004) }\end{array}$ & $\begin{array}{l}12 m+2 w \\
\text { Trained }\end{array}$ & $2 \mathrm{~h}$ & $10 \% \mathrm{O}_{2}[\mathrm{NH}]$ & $\begin{array}{l}50 \mathrm{mg} 1 \mathrm{~h} \\
\text { before test }\end{array}$ & $W_{\text {peak }}$ \\
\hline $\begin{array}{l}\text { Ghofrani } \\
\text { et al. (2004) }\end{array}$ & $\begin{array}{l}14 \mathrm{~m} \\
\text { Trained }\end{array}$ & 6 days & $5400 \mathrm{~m}-\mathrm{HH}$ & $\begin{array}{l}50 \mathrm{mg} \\
1 \mathrm{hr} \text { before } \\
\text { test }\end{array}$ & $W_{\text {peak }}$ \\
\hline $\begin{array}{l}\text { Richalet } \\
\text { et al. (2005) }\end{array}$ & $\begin{array}{l}12 \mathrm{~m} \\
\text { Moderately } \\
\text { Trained }\end{array}$ & 6 days & $\mathrm{SL}$ vs $4350 \mathrm{~m}-\mathrm{HH}$ & $\begin{array}{l}40 \mathrm{mg} \\
3 \text { times at } \\
\text { day }\end{array}$ & $\begin{array}{l}\mathrm{VO}_{2 \max } \mathrm{SL} \\
\text { (pre)// } \mathrm{VO}_{2 \max } \mathrm{HH} \\
\text { at day } 2, \\
5 / / \mathrm{VO}_{2 \max } \mathrm{SL} \\
\text { (post) }\end{array}$ \\
\hline $\begin{array}{l}\text { Ricart et al. } \\
(2005)\end{array}$ & $\begin{array}{l}14 \mathrm{~m} \\
\text { Untrained }\end{array}$ & $90 \mathrm{~min}$ & $5000 m-H H$ & $\begin{array}{l}100 \mathrm{mg} \\
45 \mathrm{~min} \\
\text { before test }\end{array}$ & $\begin{array}{l}50 \% \text { of theoretical } \\
\mathrm{VO}_{2 \max } \text { by } 5 \text { min at } \\
\mathrm{SL} \text { and } \mathrm{HH}\end{array}$ \\
\hline $\begin{array}{l}\text { Hsu et al. } \\
(2006)\end{array}$ & $\begin{array}{l}10 \mathrm{~m} \\
\text { Trained }\end{array}$ & $90 \mathrm{~min}$ & $\begin{array}{l}12.8 \% \\
\mathrm{O}_{2}=(3900 \mathrm{~m})[\mathrm{NH}]\end{array}$ & $\begin{array}{l}50 / 100 \mathrm{mg} \\
1 \mathrm{~h} \text { before } \\
\text { test }\end{array}$ & $\begin{array}{l}\mathrm{W}_{\text {peak }} \mathrm{SL}+55 \% \text { of } \\
\mathrm{W}_{\text {peak }} 60 \mathrm{~min} \\
\mathrm{SL}+10 \mathrm{TT} / / \mathrm{W}_{\text {peak }} \\
\mathrm{NH}+55 \% 30 \mathrm{~min} \\
\mathrm{NH}+6 \mathrm{TT}\end{array}$ \\
\hline $\begin{array}{l}\text { Faoro et al. } \\
(2007)\end{array}$ & $\begin{array}{l}8 m+6 w \\
\text { Untrained }\end{array}$ & $1 \mathrm{~h}$ & $\begin{array}{l}11 \% \mathrm{O}_{2}=(5000 \mathrm{~m}) \\
{[\mathrm{NH}]} \\
\text { vs } 10 \text { days at } \\
5000 \mathrm{~m}[\mathrm{HH}]\end{array}$ & $\begin{array}{l}50 \mathrm{mg} \\
30 \mathrm{~min} \\
\text { before test }\end{array}$ & $W_{\text {peak }}$ \\
\hline $\begin{array}{l}\text { Kressler } \\
\text { et al. (2011) }\end{array}$ & $\begin{array}{l}11 m+10 w \\
\text { Trained }\end{array}$ & $1 \mathrm{~h}$ & $\begin{array}{l}16.2 \% \\
\mathrm{O}_{2}=(2100 \mathrm{~m}) \mathrm{vs} \\
11 \% \mathrm{O}_{2}=(5000 \mathrm{~m}) \\
{[\mathrm{NH}]} \\
12.8 \% \\
\mathrm{O}_{2}=(3900 \mathrm{~m}) \mathrm{vs} \\
11 \% \mathrm{O}_{2}=(5000 \mathrm{~m}) \\
{[\mathrm{NH}]}\end{array}$ & $\begin{array}{l}50 \mathrm{mg} \\
1 \mathrm{~h} \text { before } \\
\text { test }\end{array}$ & $\begin{array}{l}\mathrm{W}_{\text {peak }} \text { and } 55 \% \\
\mathrm{~W}_{\text {peak }} \text { by } \\
30 \mathrm{~min}+15 \mathrm{~km} \text { (SL } \\
\text { vs } \mathrm{NH})\end{array}$ \\
\hline $\begin{array}{l}\text { Jacobs } \\
\text { et al. (2011) }\end{array}$ & $\begin{array}{l}20 m+15 w \\
\text { Trained }\end{array}$ & $60 \mathrm{~min}$ & $\begin{array}{l}12.8 \% \\
\mathrm{O}_{2}=(3900 \mathrm{~m}) \mathrm{vs} \\
11 \% \mathrm{O}_{2}=(5000 \mathrm{~m}) \\
{[\mathrm{NH}]}\end{array}$ & $\begin{array}{l}50 \mathrm{mg} \\
1 \mathrm{~h} \text { before } \\
\text { test }\end{array}$ & $\begin{array}{l}\mathrm{W}_{\text {peak }} \text { and } 55 \% \\
\mathrm{~W}_{\text {peak }} \text { (alt. sp.) by } \\
30 \mathrm{~min}+6 \mathrm{~km} \text { (SL } \\
\text { vs } \mathrm{NH})\end{array}$ \\
\hline $\begin{array}{l}\text { Olfert et al. } \\
(2011)\end{array}$ & $\begin{array}{l}8 m+8 w \\
\text { Trained }\end{array}$ & $90 \min$ & $\begin{array}{l}11 \% \mathrm{O}_{2}=(5000 \mathrm{~m}) \\
{[\mathrm{NH}]}\end{array}$ & $\begin{array}{l}50 \mathrm{mg} \\
1 \mathrm{~h} \text { before } \\
\text { test }\end{array}$ & $\begin{array}{l}\left(\mathrm{W}_{\text {peak }}\right) \text { and } 15 \%, \\
45 \% \text { and } 90 \% \text { of } \\
\mathrm{VO}_{2 \max }\end{array}$ \\
\hline $\begin{array}{l}\text { Toro et al. } \\
(2015)\end{array}$ & $4 m+4 w$ & $90 \mathrm{~min}$ & $4000 \mathrm{~m}-\mathrm{HH}$ & $\begin{array}{l}50 \mathrm{mg} \\
1 \mathrm{~h} \text { before } \\
\text { test }\end{array}$ & $\begin{array}{l}\mathrm{W}_{\text {peak }} \text { and } 60 \% \text { of } \\
\mathrm{W}_{\text {peak }} \text { by } 6 \mathrm{~min} \text { at } \\
\mathrm{SL} \text { and } \mathrm{HH}\end{array}$ \\
\hline
\end{tabular}

Abbreviations: $\mathrm{m}=\mathrm{men} ; \mathrm{w}=$ women; $\mathrm{NH}=$ normobaric hypoxia; $\mathrm{HH}=$ hypobaric hypoxia; $\mathrm{SL}=$ sea level; $\mathrm{W}_{\text {peak }}=$ maximum workload; $\mathrm{TT}=$ time trial; alt. $\mathrm{sp}=$ specific for altitude.

rest and during exercise. After sildenafil administration, the oxygen saturation $\left(\mathrm{SaO}_{2}\right)$ was improved in acute induced (normobaric) hypoxia but not in the natural high altitude (hypobaric) hypoxia conditions. CO increased under both hypoxic conditions, whilst the systemic blood pressures were not affected by sildenafil. $W_{\text {peak }}$ improved by $32 \%$ in normobaric hypoxia and by $11 \%$ in hypobaric hypoxia. The main conclusion of the study was that sildenafil reduced hypoxic pulmonary hypertension at rest and during exercise, most likely due to the reduction in right ventricular afterload, thus keeping an adequate gas exchange and systemic arterial pressure and increasing exercise capacity during severe hypoxia.
Richalet et al. ${ }^{29}$ exposed 12 healthy men (not acclimated to altitude with a moderate physical condition) for 6 days at an altitude of $4350 \mathrm{~m}$. The treatment was to take one dose of $40 \mathrm{mg}$ of sildenafil or placebo, three times a day (8:00 am; 2:00 pm and 8:00 pm). Measurements of systemic and pulmonary blood pressure, $\mathrm{CO}$ and $\mathrm{SaO}_{2}$, were taken during 12 days, 3 times a day. Days 1-3 were taken at sea level (SL), measurements of days 5-10 were taken at high altitude (HA), and day 12 was taken at SL once again, after exposure to HA. Several $W_{\text {peak }}$ tests were performed. Two of them were performed at SL, one pre-ascent and the other post-ascent and 2 tests every 3 days at altitude. In hypoxia, $\mathrm{VO}_{2 \max }$ decreased from 29 to $25 \%$ after administration of sildenafil and from 
39 to $35 \%$ with placebo, but in the second test performed at altitude, $\mathrm{VO}_{2 \max }$ was higher than the first test due to acclimatization. After sildenafil administration, PHV decreased and $\mathrm{SaO}_{2}$ was significantly higher compared to placebo at altitude. Systemic blood pressure and CO were not modified by sildenafil. It was concluded that sildenafil protects against the development of pulmonary hypertension induced by altitude, improving gas exchange, limiting the altitude-induced hypoxemia and decreasing exercise performance, and did not alter normal physiological processes of acclimatization. In hypoxia, $\mathrm{VO}_{2 \max }$ decreased from 29 to $25 \%$ after sildenafil administration and from $39-35 \%$ with placebo, but the second test performed at altitude, $\mathrm{VO}_{2 \max }$ was higher than the first test due to acclimatization. After sildenafil administration, PHV decreased and $\mathrm{SaO}_{2}$ was significantly higher compared to placebo at altitude. Systemic blood pressure and $\mathrm{CO}$ were not modified by sildenafil. The main conclusion was that sildenafil protected against the development of pulmonary hypertension induced by altitude, improving gas exchange, limiting the altitude-induced hypoxemia and decreasing exercise performance, and did not alter normal physiological processes of acclimatization.

Ricart et al. ${ }^{30}$ showed data of two $\mathrm{W}_{\text {peak }}$ tests ( $5 \mathrm{~min}, 50 \%$ of $\mathrm{VO}_{2 \max }$ ) performed in non-consecutive days under both normoxia and hypobaric hypoxia ( $1 \mathrm{~h}$ at a simulated altitude of $5000 \mathrm{~m}$ ) conditions. Their study involved 14 healthy men without HA experience to whom $100 \mathrm{mg}$ of sildenafil or placebo were administered $45 \mathrm{~min}$ before each test. Sildenafil reduced the PAP at rest and during exercise in hypoxia whilst in normoxia were no changes associated with the drug. $\mathrm{SaO}_{2}$ remained unchanged during normoxia and hypoxia at rest, but in hypoxia during exercise $\mathrm{SaO}_{2}$ increased slightly. Heart rate (HR) showed a minor rise with sildenafil during rest in normoxia and hypoxia, during exercise increased in normoxia, but in hypoxia did not change. The main conclusions of the study were that sildenafil decreases pulmonary hypertension induced by acute exposure to hypoxia and may be useful for the modulation of PAP. It should be noted that exercise during exposure to simulated hypobaric hypoxia was intense but very short (5 min). PAP was measured a few minutes of arrival of simulated altitude, and probably maximal PAP was not reached and could be underestimated.

Hsu et al. ${ }^{18}$ reported data on 10 trained men, cyclists and triathletes, who performed a peak work capacity test $\left(W_{\text {peak }}\right)$ at SL followed by four exercise tests (1 practice, 3 experimental). The same procedure was used during hypoxic gas breathing (12.8\% oxygen; equivalent to $3874 \mathrm{~m}$ ) to simulate HA. All exercise tests were interspersed at least 3 days. Placebo or $100 \mathrm{mg}$ of sildenafil were administered at random during the experimental tests. The tests were performed in normoxia to $55 \%$ of $W_{\text {peak }}$ for $60 \mathrm{~min}, 5 \mathrm{~min}$ break and one time-trial test of $10 \mathrm{~km}$. In $\mathrm{HA}$ the test was performed to $55 \%$ of $W_{\text {peak }}$ for $30 \mathrm{~min}, 5 \mathrm{~min}$ break and one time-trial test of $6 \mathrm{~km}$. In SL, the parameters evaluated at rest and exercise were not modified by any dose of sildenafil, nor during of effort tests. In $\mathrm{HA}$, during exercise at $55 \% \mathrm{~W}_{\text {peak }}$, sildenafil increased $\mathrm{SaO}_{2}$ by approximately $5 \%$; CO increased by about $20 \%$, stroke volume (SV) increased around $17 \%$ and systolic blood pressure decreased in a $9 \%$. In time-trial test in hypoxia the results showed that using sildenafil, total time was less $(-15 \%)$, and that watts $(16 \%)$, CO $(8.4 \%)$ and
$\mathrm{SaO}_{2}(5.4 \%)$ increased in comparison to placebo. One of the most important findings of the investigation was that six subjects experienced no improvement in the time-trial test in hypoxia after sildenafil administration, whilst four subjects showed a good response to sildenafil administration since they increased the time duration in $39 \%$. Responders also showed increases in $\mathrm{CO}$ by $25 \%$ at rest and $32 \%$ during exercise $\left(55 \% \mathrm{~W}_{\text {peak }}\right)$ in HA. Another remarkable data was that SV in exercise at $55 \% \mathrm{~W}_{\text {peak }}$ after placebo administration led to a greater drop in responders $(26 \%)$ than in no responders $(2.3 \%)$, from $\mathrm{SL}$ to $\mathrm{HA}$, thus suggesting a strong relationship between the higher values of SV obtained by responders in exercise at SL and the decrement suffered during HA. Because PAH was not determined, it was not possible to verify if the responders could have had greater $\mathrm{PAH}$ and a consequent reduced cardiac filling which could explain their good response to sildenafil treatment. The main conclusion was that in acute hypoxia, sildenafil might improve cardiovascular function, $\mathrm{SaO}_{2}$ and performance only in some individuals (responders) and also that positive sildenafil responders could potentially be identified by their SV reduction upon acute hypoxic exposure.

Faoro et al. ${ }^{14}$ evaluated the effect of the administration of a $50 \mathrm{mg}$ dose of sildenafil in 14 healthy subjects (6 women and 8 men) not acclimatized to the altitude. Measurements were performed in normoxia, acute normobaric hypoxia $\left(10 \% \mathrm{FiO}_{2}\right.$, equivalent to $\left.5500 \mathrm{~m}\right)$ and after two weeks of acclimatization to $5000 \mathrm{~m}$ in the Mount Chimborazo defined as chronic hypoxia $(\mathrm{CH})$. At rest, sildenafil increased $\mathrm{HR}$ and $\mathrm{CO}$, whereas pulmonary vascular resistance (PVR) decreased both in normoxia, $\mathrm{AH}$ and $\mathrm{CH}$. Mean pulmonary arterial pressure also decreased in $\mathrm{AH}$ and $\mathrm{CH}$ although systolic pulmonary arterial pressure decreased only in $\mathrm{AH}$. During exercise in $\mathrm{AH}$, sildenafil increased $\mathrm{VO}_{2 \max }, \mathrm{O}_{2}$ pulse, $\mathrm{HR}$ and $\mathrm{SaO}_{2}$. In $\mathrm{CH}$, sildenafil increased $\mathrm{VO}_{2 \max }$ and $\mathrm{O}_{2}$ pulse. Their conclusion was that sildenafil could increase exercise capacity in acute normobaric hypoxia due to an improvement in arterial oxygenation, rather than a hemodynamic effect. In spite of sildenafil increased $\mathrm{VO}_{2 \max }$ and $\mathrm{SaO}_{2}$ in $\mathrm{AH}$, it was not able to improve maximum workload or maximum respiratory exchange ratio.

Kressler et al. ${ }^{31}$ studied 21 trained cyclists and triathletes (11 men and 10 women). To determine the individual performance capacity, all subjects performed three $\mathrm{W}_{\text {peak }}$ test, one at SL and two at normobaric HA. After random administration of $50 \mathrm{mg}$ of sildenafil or placebo, 2 tests were performed at normobaric HA (3900 m; equivalent to $12.8 \%$ $\mathrm{FiO}_{2}$ ) and 2 were performed at normobaric moderate altitude $\left(2100 \mathrm{~m}\right.$; equivalent to $\left.16.2 \% \mathrm{FiO}_{2}\right)$. Every experimental test consisted in $30 \mathrm{~min}$ at $55 \%$ of altitude-specific $\mathrm{W}_{\text {peak }}$ followed by $15 \mathrm{~km}$ time-trial test. Sildenafil did not significantly affect the $\mathrm{W}_{\text {peak }}, \mathrm{HR}, \mathrm{SV}, \mathrm{CO}$ nor $\mathrm{SaO}_{2}$ in comparison with placebo in HA. In the experimental tests at $55 \%$ of $\mathrm{W}_{\text {peak }}$ after sildenafil administration at moderate altitude, HR and CO were higher than placebo. In the time-trial test, sildenafil did not improve time-trial performance. In fact, sildenafil at moderate altitude significantly reduced the average-power $(-4 \%)$ and also the speed test $(-2 \%)$ compared to placebo. Sildenafil significantly increased $\mathrm{SaO}_{2}$ values at $\mathrm{HA}(3 \%)$. The conclusions were that sildenafil had little or no influence on the supply of oxygen at rest or during exercise since it did not improve the $\mathrm{SaO}_{2}, \mathrm{CO}, \mathrm{W}_{\text {peak }}$ nor time-trial performance 
in men and women neither at moderate or high altitude. These authors concluded that the magnitude of sildenafil effects could be determined by the geographical altitude and the subsequent degree of hypoxia, thus proposing that the potential beneficial effects of sildenafil during exercise are unlikely to be obtained at altitudes less than $4000 \mathrm{~m}$.

Jacobs et al. ${ }^{32}$ studied 35 trained subjects ( 20 men and 15 women, cyclists and triathletes) that performed a $\mathrm{W}_{\text {peak }}$ test at $\mathrm{SL}$ and another in simulated $\mathrm{HA}\left(12.8 \% \mathrm{FiO}_{2}\right.$ or $\left.3900 \mathrm{~m}\right)$. Later, they performed three experimental exercise tests ( $30 \mathrm{~min}$ at $55 \%$ of altitude-specific capacity $+6 \mathrm{~km}$ time-trial) one at SL and two experimental exercise tests at simulated $\mathrm{HA}$ after ingestion of either placebo or $50 \mathrm{mg}$ sildenafil with at least $48 \mathrm{~h}$ between the tests. Sildenafil administration did not significantly affect any cardiovascular and hemodynamic variables at rest or during exercise nor improved performance and power output in most men or women compared to placebo. However, sildenafil resulted in significantly higher $\mathrm{SaO}_{2}$ values in women during exercise at $\mathrm{HA}$ compared to placebo. The efficacy of sildenafil during exercise in hypoxic conditions seemed related to the ability to increase the supply of oxygen and the subsequent effects depend on the intensity of hypoxia and individual susceptibility to PHV. May be a very small percentage of endurance-trained men and women could have relevant improvements in aerobic performance after sildenafil administration at a simulated altitude of $3900 \mathrm{~m}$.

Olfert et al. ${ }^{15}$ compared the effect of sildenafil and bosentan in 16 athletes ( 8 men and 8 women). Each subject performed two tests of $\mathrm{VO}_{2 \max }$ with two days maximum time elapsed: one day on normoxia and another in normobaric hypoxia $\left(0.11 \% \mathrm{FiO}_{2}\right.$; equivalent to $\left.5000 \mathrm{~m}\right)$. A week later, subjects performed a progressive submaximal test with intensities of $15 \%$ (light), $45 \%$ (moderate) and $90 \%$ (heavy) of $\mathrm{VO}_{2 \max }$ in hypoxia. The duration of exercise in each intensity was $5 \mathrm{~min}$ with the exception of the last intensity, which depended on individual capacity to complete the programmed workload. Subjects received only one type of treatment without informing which drug was administered (placebo was not used). The same exercise was performed before and $1 \mathrm{~h}$ after taking a single dose of sildenafil ( $50 \mathrm{mg}$ ) or bosentan $(62.5 \mathrm{mg})$ on the same day. Both drugs caused a small but significant increase in partial pressure of oxygen in arterial blood $\left(\mathrm{PaO}_{2}\right)$ and $\mathrm{SaO}_{2}(3-4 \%)$ at rest and during exercise in hypoxia, both in men and in women. On the other hand, carbon dioxide partial pressure in arterial blood $\left(\mathrm{PaCO}_{2}\right)$ decreased but only when sildenafil was administered. There were no significant changes in ventilation or in other arterial parameters. HR at rest and during exercise significantly increased after the administration of both sildenafil and bosentan in all subjects. Gender-related effects were evident in women which showed higher $\mathrm{PaO}_{2}$ and $\mathrm{SaO}_{2}$ as compared to men during exercise after both drugs administration. So, sildenafil and bosentan were able to improve pulmonary gas exchange in healthy men and women in hypoxia. However, it was not possible to assess if the slight improvements in arterial oxygenation $\left(\mathrm{PaO}_{2}\right)$ corresponded to better physical performance in hypoxia. The possibility that during hypoxic exercise such improvement in $\mathrm{PaO}_{2}$ could be physiologically relevant is suggestive, but the evidence of enhanced exercise capacity performance in healthy people using sildenafil remains elusive.
Our workgroup performed a double-blind crossover study to determine the effects of sildenafil on cardiovascular, respiratory and metabolic parameters in normoxia and during acute exposure to hypobaric hypoxia $(4000 \mathrm{~m})$ at rest and during maximal and submaximal $\left(60 \% \mathrm{VO}_{2 \max }\right)$ exercise tests in 11 volunteers non-acclimatized to altitude. One hour before testing started, sildenafil $(100 \mathrm{mg})$ or a placebo was orally administered. The first phase (maximal incremental test) started from $20 \mathrm{~W}$, and $20 \mathrm{~W}$ were added per minute until exhaustion. The second phase was a submaximal intensity test, which lasted for $6 \mathrm{~min}$ at $60 \%$ of the maximum workload reached in the first phase. The break between each of the two phases was about $30 \mathrm{~min}$, until basal heart rate was recovered. We concluded that in normoxic conditions, sildenafil did not affected performance. Similarly, no significant differences were found in cardiovascular and respiratory parameters in hypoxic conditions at rest or during exercise. The use of sildenafil to improve physical performance in non-acclimated subjects is not supported by our data. ${ }^{33}$

We have included in this review a meta-analysis study by Xu et al. ${ }^{34}$ on sildenafil effects at HA, although data about sildenafil effects during exercise were not included. These authors analyzed 5 articles, 3 of which have already been commented above. ${ }^{1,14,29}$ It was evident that sildenafil administration is able to blunt the PAP increase induced by hypoxia exposure, but it does not improved $\mathrm{SaO}_{2}$ and $\mathrm{HR}$. Moreover, acute mountain sickness symptoms were not relieved by sildenafil treatment.

In summary, different cardiovascular, ventilatory and metabolic parameters that were evaluated in several reports are presented in Table 2. Cardiovascular variables that experimented more changes after sildenafil administration were $\mathrm{HR}, \mathrm{CO}$ and $\mathrm{SaO}_{2}$, showing a certain tendency to increase their values in hypoxia. However, data are not categorical, both at rest and during exercise. The arterial blood pressure (systolic, diastolic and mean) 1,18,29,31,32 and systolic volume ${ }^{18,31,32}$ were almost not affected. Lung function parameters (ventilation, tidal volume, respiratory rate and respiratory exchange ratio) were unaffected by the drug ${ }^{14,15,18,30}$. Finally, the exercise values such as $\mathbf{W}_{\text {peak }}{ }^{1,14,15,18,29,31,32}$ or $\mathbf{V O}_{2 \max }{ }^{14,29}$ are not conclusive at all to affirm that sildenafil significantly improves performance during exposure to acute hypoxia, regardless its normobaric or hypobaric nature.

\section{Normobaric versus hypobaric hypoxia}

An important point to keep in mind when comparing all the cited reports it is to consider the difference in the hypoxia conditions (simulated or natural) and the type of hypoxia (normobaric or hypobaric) that subjects underwent, because some studies showed differences between exposition to normobaric and hypobaric hypoxia. ${ }^{35-39}$ Comparing both types of hypoxia, one study described that hypobaric hypoxia leads to greater hypoxemia, hypocapnia, alkalosis and lower blood $\mathrm{SaO}_{2}$ than normobaric conditions. These physiological differences could be the result of an increase in dead space ventilation, probably related to reduced barometric pressure in hypobaric hypoxia. ${ }^{38}$ Another research showed that some variables of heart rate variability were affected in 
Table 2 Summary changes reported by the reviewed studies in physiological parameters after sildenafil administration $v / s$ placebo.

\begin{tabular}{|c|c|c|c|c|c|c|c|c|c|}
\hline Parameters & $\begin{array}{c}\text { Ghofrani } \\
\text { et al. (2004) }\end{array}$ & $\begin{array}{c}\text { Richalet al. } \\
\text { (2005) }\end{array}$ & $\begin{array}{c}\text { Ricart et al. } \\
\text { (2005) }\end{array}$ & $\begin{array}{l}\text { Hsu et al. } \\
\text { (2006) }\end{array}$ & $\begin{array}{c}\text { Faoro et al. } \\
(2007)\end{array}$ & $\begin{array}{c}\text { Kressler } \\
\text { et al. (2011) }\end{array}$ & $\begin{array}{c}\text { Jacobs } \\
\text { et al. (2011) }\end{array}$ & $\begin{array}{l}\text { Olfert et al. } \\
\text { (2011) }\end{array}$ & $\begin{array}{c}\text { Toro et al. } \\
\text { (2015) }\end{array}$ \\
\hline PAP (mmHg) & $\begin{array}{l}\downarrow R, \\
\text { AHn-HAh } \\
\downarrow \text { Ex } \\
\text { AHn-HAh }\end{array}$ & $\downarrow$, HAh & $\begin{array}{l}\leftrightarrow \text { R-Ex; Nm } \\
\downarrow \text { R-Ex, AHh }\end{array}$ & - & $\downarrow \mathrm{R}, \mathrm{AHn}-\mathrm{CH}$ & - & - & - & - \\
\hline$W_{\text {peak }}(W)$ & $\begin{array}{l}\uparrow E x, \\
\text { AHn-HAh }\end{array}$ & $\uparrow, \mathrm{HAh}$ & - & $\begin{array}{l}\leftrightarrow \mathrm{Tt}, \mathrm{Nm} \\
\uparrow \mathrm{Tt}, \mathrm{AHn}\end{array}$ & $\begin{array}{l}\leftrightarrow \mathrm{Ex}, \\
\mathrm{AHn}-\mathrm{CH}\end{array}$ & $\begin{array}{l}\downarrow \text { Tt MAn } \\
\leftrightarrow \text { Tt AHn }\end{array}$ & $\begin{array}{l}\leftrightarrow 55 \%, \mathrm{AHn} \\
\leftrightarrow \mathrm{Tt}, \mathrm{AHn}\end{array}$ & $\leftrightarrow \mathrm{AHn}$ & $\begin{array}{l}\leftrightarrow \\
\text { R-Ex/60\%; } \\
\text { Nm-HAh }\end{array}$ \\
\hline Sys (mmHg) & $\begin{array}{l}\leftrightarrow \text { R, } \\
\text { AHn-HAh } \\
\leftrightarrow \text { Ex, } \\
\text { AHn-HAh }\end{array}$ & $\leftrightarrow, \mathrm{HAh}$ & - & $\begin{array}{l}\leftrightarrow 55 \%, \mathrm{Nm} \\
\downarrow 55 \%, \mathrm{AHn}\end{array}$ & - & $\begin{array}{l}\leftrightarrow \mathrm{R} ; \leftrightarrow \\
55 \% \\
\text { MAn-AHn }\end{array}$ & $\begin{array}{l}\leftrightarrow \mathrm{R}, 55 \%, \\
\mathrm{AHn}\end{array}$ & - & $\begin{array}{l}\leftrightarrow \\
\text { R-Ex/60\%; } \\
\text { Nm-HAh }\end{array}$ \\
\hline $\begin{array}{l}\text { HR } \\
\text { (beats/min) }\end{array}$ & $\begin{array}{l}\leftrightarrow \mathrm{R}, \\
\mathrm{AHn}-\mathrm{HAh} \\
\uparrow \mathrm{Ex}, \mathrm{HA} \\
\leftrightarrow \mathrm{Ex} \mathrm{AHn}\end{array}$ & $\downarrow$, HAh & $\begin{array}{l}\uparrow \mathrm{R}, \\
\mathrm{Nm}-\mathrm{AHh} \\
\uparrow \mathrm{Ex}, \mathrm{Nm} \\
\leftrightarrow \mathrm{Ex}, \mathrm{AHh}\end{array}$ & $\begin{array}{l}\leftrightarrow 55 \%-\mathrm{Tt}, \\
\mathrm{Nm} \\
\leftrightarrow 55 \%-\mathrm{Tt}, \\
\mathrm{AHn}\end{array}$ & $\begin{array}{l}\uparrow \mathrm{R}, \\
\mathrm{Nm}-\mathrm{AHn}-\mathrm{CH} \\
\uparrow \mathrm{Ex}, \mathrm{CH} \\
\leftrightarrow \mathrm{Ex}, \mathrm{AHn}\end{array}$ & $\begin{array}{l}\uparrow 55 \% \text { MAn } \\
\leftrightarrow \mathrm{AHn} \\
\leftrightarrow \mathrm{Tt} \\
\mathrm{MAn}-\mathrm{AHn}\end{array}$ & $\begin{array}{l}\uparrow \mathrm{R}(\mathrm{m}), \\
\mathrm{AHn} \\
\leftrightarrow 55 \%, \mathrm{AHn} \\
\leftrightarrow \mathrm{Tt}, \mathrm{AHn}\end{array}$ & $\uparrow \mathrm{AHn}$ & $\begin{array}{l}\leftrightarrow \\
\text { R-Ex/60\%; } \\
\text { Nm-HAh }\end{array}$ \\
\hline $\mathrm{SaO}_{2}(\%)$ & $\begin{array}{l}\leftrightarrow \text { R, } \\
A H n-H A h \\
\uparrow E x, A H n ; \\
\leftrightarrow E x, H A h\end{array}$ & $\uparrow, \mathrm{HAh}$ & $\begin{array}{l}\leftrightarrow \mathrm{R}, \\
\mathrm{Nm}-\mathrm{AHh} \\
\leftrightarrow \mathrm{Ex}, \mathrm{Nm} \\
\uparrow \mathrm{Ex}, \mathrm{AHh}\end{array}$ & $\begin{array}{l}\leftrightarrow 55 \%-\mathrm{Tt}, \\
\mathrm{Nm} \\
\uparrow 55 \%-\mathrm{Tt}, \\
\mathrm{AHn}\end{array}$ & $\begin{array}{l}\leftrightarrow \mathrm{R}, \\
\mathrm{Nm}-\mathrm{AHn}-\mathrm{CH} \\
\uparrow \mathrm{Ex}, \mathrm{AHn} \\
\leftrightarrow \mathrm{Ex} \\
\mathrm{Nm}-\mathrm{CH}\end{array}$ & $\begin{array}{l}\uparrow 55 \% \mathrm{AHn}- \\
\uparrow \mathrm{Tt} \mathrm{AHn} \\
\leftrightarrow \mathrm{MAn} \\
\leftrightarrow \mathrm{R}, \\
\mathrm{MAn}-\mathrm{AHn}\end{array}$ & $\begin{array}{l}\uparrow 55 \%(w), \\
\mathrm{AHn}\end{array}$ & $\uparrow \mathrm{AHn}$ & $\begin{array}{l}\leftrightarrow \\
\text { R-Ex/60\%; } \\
\text { Nm-HAh }\end{array}$ \\
\hline CO (L/min) & $\begin{array}{l}\uparrow \mathrm{R}, \mathrm{AHn} ; \leftrightarrow \\
\mathrm{R}, \mathrm{HAh} \\
\uparrow \mathrm{Ex} \\
\mathrm{AHn}-\mathrm{HAh}\end{array}$ & $\leftrightarrow, \mathrm{HAh}$ & - & $\begin{array}{l}\leftrightarrow 55 \%-\mathrm{Tt}, \\
\mathrm{Nm} \\
\uparrow 55 \%-\mathrm{Tt}, \\
\mathrm{AHn}\end{array}$ & $\begin{array}{l}\uparrow \mathrm{R} ; \mathrm{Nm}, \\
\mathrm{AHn}-\mathrm{CH}\end{array}$ & $\begin{array}{l}\uparrow 55 \% \text { MAn } \\
\leftrightarrow, \mathrm{AHn}\end{array}$ & $\begin{array}{l}\leftrightarrow \mathrm{R}, 55 \%, \\
\mathrm{AHn}\end{array}$ & - & $\begin{array}{l}\leftrightarrow \\
\text { R-Ex/60\%; } \\
\text { Nm-HAh }\end{array}$ \\
\hline Dia (mmHg) & - & $\leftrightarrow, \mathrm{HAh}$ & - & - & - & $\begin{array}{l}\leftrightarrow \mathrm{R}, 55 \% \\
\text { MAn-AHn }\end{array}$ & $\begin{array}{l}\leftrightarrow \mathrm{R}, 55 \%, \\
\mathrm{AHn}\end{array}$ & - & $\begin{array}{l}\leftrightarrow \text { R-Ex/Nm } \\
\downarrow 60 \% ; H A h\end{array}$ \\
\hline $\mathrm{VO}_{2 \max }$ & - & $\uparrow, \mathrm{HAh}$ & - & - & $\begin{array}{l}\uparrow \mathrm{Ex}, \mathrm{AHn} \\
\leftrightarrow \mathrm{Ex}, \mathrm{CH}\end{array}$ & - & - & - & - \\
\hline $\begin{array}{l}\text { RR } \\
\text { (breaths } \text { min }^{-1} \text { ) }\end{array}$ & - & - & $\begin{array}{l}\leftrightarrow \text { R-Ex, } \\
\mathrm{Nm}-\mathrm{AHh}\end{array}$ & - & - & - & - & - & $\begin{array}{l}\leftrightarrow \\
\text { R-Ex/60\%; } \\
\text { Nm-HAh }\end{array}$ \\
\hline $\mathrm{V}_{\mathrm{T}}\left(\mathrm{L} \min ^{-1}\right)$ & - & - & $\begin{array}{l}\leftrightarrow \text { R-Ex, } \\
\text { Nm-AHh }\end{array}$ & - & - & - & - & - & $\begin{array}{l}\leftrightarrow \\
\text { R-Ex/60\%; } \\
\text { Nm-HAh }\end{array}$ \\
\hline
\end{tabular}


Table 2 (Continued)

\begin{tabular}{|c|c|c|c|c|c|c|c|c|c|}
\hline Parameters & $\begin{array}{c}\text { Ghofrani } \\
\text { et al. (2004) }\end{array}$ & $\begin{array}{c}\text { Richalet al. } \\
\text { (2005) }\end{array}$ & $\begin{array}{c}\text { Ricart et al. } \\
\text { (2005) }\end{array}$ & $\begin{array}{l}\text { Hsu et al. } \\
\text { (2006) }\end{array}$ & $\begin{array}{c}\text { Faoro et al. } \\
\text { (2007) }\end{array}$ & $\begin{array}{l}\text { Kressler } \\
\text { et al. (2011) }\end{array}$ & $\begin{array}{c}\text { Jacobs } \\
\text { et al. (2011) }\end{array}$ & $\begin{array}{l}\text { Olfert et al. } \\
\text { (2011) }\end{array}$ & $\begin{array}{c}\text { Toro et al. } \\
\text { (2015) }\end{array}$ \\
\hline Efr (\%) & - & - & $\begin{array}{l}\leftrightarrow \text { R-Ex, } \\
\mathrm{Nm}-\mathrm{AHh}\end{array}$ & - & - & - & - & - & - \\
\hline$V_{E}\left(L_{m i n}^{-1}\right)$ & - & - & $\begin{array}{l}\leftrightarrow \text { R-Ex } \\
\text { Nm-AHh }\end{array}$ & - & $\begin{array}{l}\leftrightarrow \text { Ex } \\
\text { Nm-AHn-CH }\end{array}$ & - & - & $\leftrightarrow \mathrm{AHn}$ & $\begin{array}{l}\leftrightarrow \\
\text { R-Ex/60\%; } \\
\text { Nm-HAh }\end{array}$ \\
\hline $\begin{array}{l}\text { SV } \\
\left(\mathrm{ml} \mathrm{beat}^{-1}\right)\end{array}$ & - & - & - & $\begin{array}{l}\leftrightarrow 55 \%-\mathrm{Tt}, \\
\mathrm{Nm} \\
\uparrow 55 \%, \mathrm{AHn} \\
\leftrightarrow \mathrm{Tt}, \mathrm{AHn}\end{array}$ & - & $\leftrightarrow \mathrm{MAn}-\mathrm{AHn}$ & $\begin{array}{l}\leftrightarrow \text { R, 55\%, } \\
\mathrm{AHn}\end{array}$ & - & $\begin{array}{l}\leftrightarrow \\
\text { R-Ex/60\%; } \\
\text { Nm-HAh }\end{array}$ \\
\hline RPE & - & - & - & $\begin{array}{l}\leftrightarrow 55 \% \\
\mathrm{Nm}-\mathrm{AHn}\end{array}$ & - & $\begin{array}{l}\leftrightarrow \mathrm{R}, 55 \%, \\
\text { MAn-AHn }\end{array}$ & $\leftrightarrow 55 \%, \mathrm{AHn}$ & - & - \\
\hline Tt (min) & - & - & - & $\begin{array}{l}\leftrightarrow 55 \%-\mathrm{Tt}, \\
\mathrm{Nm} \\
\downarrow \mathrm{Tt}, \mathrm{AHn}\end{array}$ & - & $\begin{array}{l}\uparrow \mathrm{Tt} \text { MAn; } \\
\leftrightarrow \mathrm{AHn}\end{array}$ & $\leftrightarrow, \mathrm{Tt}, \mathrm{AHn}$ & - & - \\
\hline RER & - & - & - & $\leftrightarrow 55 \%, \mathrm{Nm}$ & $\begin{array}{l}\leftrightarrow \mathrm{Ex} \\
\mathrm{AHn}-\mathrm{CH}\end{array}$ & - & - & $\leftrightarrow \mathrm{AHn}$ & $\begin{array}{l}\overleftrightarrow{\leftrightarrow} \\
\text { R-Ex/60\%; } \\
\text { Nm-HAh }\end{array}$ \\
\hline TAM (mmHg) & - & - & - & - & $\begin{array}{l}\leftrightarrow \mathrm{R}, \\
\mathrm{AHn}-\mathrm{CH}\end{array}$ & - & - & - & $\begin{array}{l}\overleftrightarrow{\leftrightarrow} \text { R-Ex/60\%; } \\
\text { Nm-HAh }\end{array}$ \\
\hline $\begin{array}{l}\mathrm{O}_{2} \text { pulse }(\mathrm{ml} \\
\left.\text { beat }^{-1}\right)\end{array}$ & - & - & - & - & $\begin{array}{l}\uparrow \mathrm{Ex}, \mathrm{AHn} ; \\
\leftrightarrow \mathrm{Ex}, \mathrm{CH}\end{array}$ & - & - & - & $\begin{array}{l}\leftrightarrow \\
\text { R-Ex/60\%; } \\
\text { Nm-HAh }\end{array}$ \\
\hline $\mathrm{V}_{\mathrm{E}} / \mathrm{VCO}_{2}(\mathrm{~L})$ & - & - & - & - & $\begin{array}{l}\leftrightarrow \mathrm{Ex} \\
\mathrm{AHn}-\mathrm{CH}\end{array}$ & - & - & - & $\begin{array}{l}\leftrightarrow \\
\text { R-Ex/60\%; } \\
\text { Nm-HAh }\end{array}$ \\
\hline $\begin{array}{l}\mathrm{VO}_{2} \\
\left(\mathrm{~L} \mathrm{~min}^{-1}\right)\end{array}$ & - & - & - & $\leftrightarrow 55 \%, \mathrm{Nm}$ & $\begin{array}{l}\leftrightarrow \text { Ex } \\
\mathrm{AHn}-\mathrm{CH}\end{array}$ & - & - & $\leftrightarrow \mathrm{AHn}$ & $\begin{array}{l}\leftrightarrow \\
\text { R-Ex/60\%; } \\
\text { Nm-HAh }\end{array}$ \\
\hline $\begin{array}{l}\text { Speed } \\
\left(\mathrm{Km} \mathrm{h}^{-1}\right)\end{array}$ & - & - & - & - & - & $\begin{array}{l}\downarrow \text { Tt MAn; } \\
\leftrightarrow \mathrm{AHn}\end{array}$ & - & - & - \\
\hline $\begin{array}{l}\mathrm{VCO}_{2} \\
\left(\mathrm{~L} \mathrm{~min}^{-1}\right)\end{array}$ & - & - & - & - & - & - & - & $\leftrightarrow \mathrm{AHn}$ & $\begin{array}{l}\leftrightarrow \\
\text { R-Ex/60\%; } \\
\text { Nm-HAh }\end{array}$ \\
\hline
\end{tabular}

Abbreviations and symbols: $\uparrow=$ sildenafil increased compared to placebo; $\downarrow=$ sildenafil decreased compared to placebo; $\leftrightarrow=$ no changes; $(-)=$ not evaluated; AHh = acute hypoxia (hypobaric); $\mathrm{AHn}=$ acute hypoxia (normobaric); $\mathrm{CH}=$ chronic hypoxia; $\mathrm{CO}=$ cardiac output; Dia = diastolic blood pressure; $\mathrm{Efr}=$ ejection fraction; $\mathrm{Ex}=\mathrm{exercise;} \mathrm{Hah=} \mathrm{high} \mathrm{altitude} \mathrm{(hypobaric);} \mathrm{HR=} \mathrm{heart}$ rate; $(\mathrm{m})=$ men; Man = moderate hypoxia (normobaric); $M A P=$ mean arterial pressure; $\mathrm{Nm}=$ normoxia; $\mathrm{O}_{2}$ Pulse = oxygen pulse; PAP = pulmonary artery pressure; $\mathrm{R}=$ rest; RER = respiratory exchange ratio; $\mathrm{RPE}=$ rating of perceived exertion; $\mathrm{RR}=$ respiratory rate; $\mathrm{SaO}_{2}=$ arterial oxygen saturation; $\mathrm{SV}=$ stroke volume; Sys = systolic blood pressure; $\mathrm{Tt}=$ trial time; $\mathrm{V}_{\mathrm{E}}=\mathrm{volume}$ of expired air; $\mathrm{V}_{\mathrm{E}} / \mathrm{VCO}_{2}=$ respiratory equivalent for carbon dioxide; $\mathrm{VO}_{2}=$ oxygen consumption; $\mathrm{VO}_{2 m a x}=$ maximum oxygen uptake; $\mathrm{VCO}_{2}=$ production of carbon dioxide; $\mathrm{V}_{\mathrm{T}}=$ tidal volume; $(\mathrm{W})=$ women; $\mathrm{W}_{\text {peak }}=$ maximal workload; $55 \%=55 \%$ of $\mathrm{VO}_{2 \mathrm{max}} ; 60 \%=60 \%$ of $\mathrm{W}_{\text {peak }}$ obtained in maximal test. 
hypobaric hypoxia but not in normobaric hypoxia. ${ }^{35}$ However, other factors such as time of exposure to hypoxia, the previous history of acclimatization, temperature or humidity should be considered as possible causes of these differences. Furthermore, the small sample sizes in many studies may also limit the conclusions that can be drawn from the results. ${ }^{39}$

\section{Conclusions}

Due that initial research on the effects of sildenafil on pulmonary circulation were conducted in patients with cardiopulmonary disease, it was possible to early confirm that sildenafil is an effective vasodilator of the pulmonary arteries also in healthy people, whether in the hypobaric hypoxia or under normobaric conditions. 1,14,29,30

However, it has been ruled out any performance improvement under normoxic conditions after sildenafil administration. Those, the use of sildenafil as an ergogenic substance under normoxic conditions, or combining sildenafil with anabolic steroids to achieve a better oxygenation of the muscle fibers to elicit their hypertrophy lacks of scientific evidence.

Considering the current ambiguity regarding the real ability of sildenafil to improve athletic performance, studies concur that the effectiveness of sildenafil during exercise at altitude is related to its ability to improve the oxygen supply to increase $\mathrm{SaO}_{2}$ and/or cardiac output. The magnitude of these effects appears to be determined by the severity of hypoxemia and hypoxia and the individual susceptibility to hypoxic pulmonary vasoconstriction and individual response to the drug's effect.

Based on present data, it seems unlikely that sildenafil may exert beneficial effects in oxygen delivery or $\mathrm{CaO}_{2}$ during intense exercise at altitudes less than $4000 \mathrm{~m}$. Considering that, except for climbers, no other sport is practiced at this altitude, the use of sildenafil as an ergogenic aid does seems ineffective. On the contrary, possible adverse effects may be caused by this drug, such as headaches, hypotension or other cardiovascular and hemodynamic unbalances.

More research on the effects of sildenafil or other PDE-5 inhibitors (tadalafil or vardenafil) at altitude still have to be clarified. The dosage of the drug, the degree of acclimatization of the subjects and the exercise intensity are variables that must be controlled in order to evaluate the real beneficial effects on exercise performance during acute hypoxia exposure.

\section{Conflict of interest}

The authors manifest that they have NO affiliations with or involvement in any organization or entity with any financial interest (such as honoraria; educational grants; participation in speakers' bureaus; membership, employment, consultancies, stock ownership, or other equity interest; and expert testimony or patent-licensing arrangements), or non-financial interest (such as personal or professional relationships, affiliations, knowledge or beliefs) in the subject matter or materials discussed in this manuscript.

\section{References}

1. Ghofrani HA, Reichenberger F, Kohstall MG, Mrosek EH, Seeger $\mathrm{T}$, Olschewski $\mathrm{H}$, et al. Sildenafil increased exercise capacity during hypoxia at low altitudes and at Mount Everest base camp: a randomized, double-blind, placebo-controlled crossover trial. Ann Intern Med. 2004;141:169-77.

2. Boolell M, Gepi-Attee S, Gingell JC, Allen MJ. Sildenafil, a novel effective oral therapy for male erectile dysfunction. Br J Urol. 1996;78:257-61.

3. Jackson G, Benjamin N, Jackson N, Allen MJ. Effects of sildenafil citrate on human hemodynamics. Am J Cardiol. 1999;83(5A):13C-20C.

4. Sanchez LS, de la Monte SM, Filippov G, Jones RC, Zapol WM, Bloch KD. Cyclic-GMP-binding, cyclic-GMP-specific phosphodiesterase (PDE5) gene expression is regulated during rat pulmonary development. Pediatr Res. 1998;43:163-8.

5. Abrams D, Schulze-Neick I, Magee AG. Sildenafil as a selective pulmonary vasodilator in childhood primary pulmonary hypertension. Heart. 2000;84:E4.

6. Guazzi MDM, Tumminello G, Di Marco F, Fiorentini C, Guazzi MDM. The effects of phosphodiesterase- 5 inhibition with sildenafil on pulmonary hemodynamics and diffusion capacity, exercise ventilatory efficiency, and oxygen uptake kinetics in chronic heart failure. J Am Coll Cardiol. 2004;44:2339-48.

7. Aldashev AA, Kojonazarov BK, Amatov TA, Sooronbaev TM, Mirrakhimov MM, Morrell NW, et al. Phosphodiesterase type 5 and high altitude pulmonary hypertension. Thorax. 2005;60:683-7.

8. Blanco I, Gimeno E, Munoz PA, Pizarro S, Gistau C, RodriguezRoisin R, et al. Hemodynamic and gas exchange effects of sildenafil in patients with chronic obstructive pulmonary disease and pulmonary hypertension. Am J Respir Crit Care Med. 2010;181:270-8.

9. Blanco I, Santos S, Gea J, Güell R, Torres F, Gimeno-Santos E, et al. Sildenafil to improve respiratory rehabilitation outcomes in COPD: a controlled trial. Eur Respir J. 2013;42:982-92.

10. Zisman DA, Schwarz M, Anstrom KJ, Collard HR, Flaherty KR, Hunninghake GW. A controlled trial of sildenafil in advanced idiopathic pulmonary fibrosis. N Engl J Med. 2010;363:620-8.

11. Palmer BF. Physiology and pathophysiology with ascent to altitude. Am J Med Sci. 2010;340:69-77.

12. Swenson ER. Hypoxic pulmonary vasoconstriction. High Alt Med Biol. 2013;14:101-10.

13. Sylvester JT, Shimoda LA, Aaronson PI, Ward JPT. Hypoxic pulmonary vasoconstriction. Physiol Rev. 2012;92:367-520.

14. Faoro V, Lamotte M, Deboeck G, Pavelescu A, Huez S, Guenard $\mathrm{H}$, et al. Effects of sildenafil on exercise capacity in hypoxic normal subjects. High Alt Med Biol. 2007;8:155-63.

15. Olfert IM, Loeckinger A, Treml B, Faulhaber $M$, Flatz $M$, Burtscher $M$, et al. Sildenafil and bosentan improve arterial oxygenation during acute hypoxic exercise: a controlled laboratory trial. Wilderness Environ Med. 2011;22:211-21.

16. West JB. The physiologic basis of high-altitude diseases. Ann Intern Med. 2004;141:789-800.

17. Calbet JA, Boushel R, Rådegran G, Søndergaard H, Wagner PD, Saltin B. Determinants of maximal oxygen uptake in severe acute hypoxia. Am J Physiol Regul Integr Comp Physiol. 2003;284:R291-303.

18. Hsu AR, Barnholt KE, Grundmann NK, Lin JH, McCallum SW, Friedlander AL. Sildenafil improves cardiac output and exercise performance during acute hypoxia, but not normoxia. J Appl Physiol. 2006;100:2031-40.

19. Naeije R. Physiological adaptation of the cardiovascular system to high altitude. Prog Cardiovasc Dis. 2010;52:456-66.

20. Bärtsch P, Mairbäurl H, Maggiorini M, Swenson ER. Physiological aspects of high-altitude pulmonary edema. J Appl Physiol. 2005;98:1101-10. 
21. Dehnert C, Risse F, Ley S, Kuder TA, Buhmann R, Puderbach $M$. Magnetic resonance imaging of uneven pulmonary perfusion in hypoxia in humans. Am J Respir Crit Care Med. 2006;174:1132-8.

22. Naeije R, Huez S, Lamotte M, Retailleau K, Neupane S, Abramowicz D, et al. Pulmonary artery pressure limits exercise capacity at high altitude. Eur Respir J. 2010;36: 1049-55.

23. SPORT.ES. River Plate: Viagra para dar la talla ante el "mal de altura"'. SPORT.ES; 2015, February 18 [Internet] Available from: http://www.sport.es/es/noticias/futbol-america/river-plateviagra-para-dar-talla-ante-mal-altura-3949790

24. Pérez R. Un equipo peruano usa Viagra para combatir el mal de altura. Diario AS. 2013, February 25 [Internet] Available from: http://futbol.as.com/futbol/2013/02/25/internacional/ 1361823526_821123.html

25. Yarroch G. Los jugadores de River tomarán Viagra para jugar en la altura. Diario El Clarín; 2015, February 18 [Internet] Available from: http://www.clarin.com/deportes/ futbol/river-plate/jugadores-River-tomaran-Viagra-altura_0_ 1306069609.html

26. Diario Los Andes. Futbolistas bolivianos usaron Viagra para jugar en la altura. Diario Los Andes; 2009, April 17 [Internet] Available from: http://archivo.losandes.com.ar/notas/ 2009/4/17/un-419233.asp

27. Diario $A B C$. Viagra contra el mal de altura. Diario $A B C$; 2014, July 30 [Internet] Available from: http://www.abc.es/ deportes/futbol/20140730/abci-lorenzo-viagra-bolivar-altura201407292000.html

28. Kent LT. Sildenafil and Bodybuilding. LIVESTRONG.COM; 2015, February 17 [Internet] Available from: http://www.livestrong. com/article/311616-sildenafil-and-bodybuilding/

29. Richalet J-P, Gratadour P, Robach P, Pham I, Déchaux M, Joncquiert-Latarjet A, et al. Sildenafil inhibits altitude-induced hypoxemia and pulmonary hypertension. Am J Respir Crit Care Med. 2005;171:275-81.
30. Ricart A, Maristany J, Fort N, Leal C, Pagés T, Viscor G. Effects of sildenafil on the human response to acute hypoxia and exercise. High Alt Med Biol. 2005;6:43-9.

31. Kressler J, Stoutenberg M, Roos BA, Friedlander AL, Perry AC, Signorile JF, et al. Sildenafil does not improve steady state cardiovascular hemodynamics, peak power, or $15-\mathrm{km}$ time trial cycling performance at simulated moderate or high altitudes in men and women. Eur J Appl Physiol. 2011;111:3031-40.

32. Jacobs KA, Kressler J, Stoutenberg M, Roos BA, Friedlander AL. Sildenafil has little influence on cardiovascular hemodynamics or 6-km time trial performance in trained men and women at simulated high altitude. High Alt Med Biol. 2011;12:215-22.

33. Toro-Salinas A, Fort N, Torrella JR, Pagès T, Javierre C, Viscor G. Sildenafil does not improve exercise capacity under acute hypoxia exposure. Int J Sports Med. 2015 (in press).

34. Xu Y, Liu Y, Liu J, Qian G. Meta-analysis of clinical efficacy of sildenafil, a phosphodiesterase type- 5 inhibitor on high altitude hypoxia and its complications. High Alt Med Biol. 2014;15:46-51.

35. Basualto-Alarcón C, Rodas G, Galilea PA, Riera J, Pagés T, Ricart A, et al. Cardiorespiratory parameters during submaximal exercise under acute exposure to normobaric and hypobaric hypoxia. Apunt Med l'Esport. 2012;47:65-72.

36. Faiss R, Pialoux V, Sartori C, Faes C, Dériaz O, Millet GP. Ventilation, oxidative stress, and nitric oxide in hypobaric versus normobaric hypoxia. Med Sci Sports Exerc. 2013;45:253-60.

37. Richard NA, Koehle MS. Differences in cardio-ventilatory responses to hypobaric and normobaric hypoxia: a review. Aviat Space Environ Med. 2012;83:677-84.

38. Savourey G, Launay J-C, Besnard Y, Guinet A, Travers S. Normoand hypobaric hypoxia: are there any physiological differences? Eur J Appl Physiol. 2003;89:122-6.

39. Coppel J, Hennis P, Gilbert-Kawai E, Grocott MP. The physiological effects of hypobaric hypoxia versus normobaric hypoxia: a systematic review of crossover trials. Extrem Physiol Med. 2015;4:2. 